\title{
HUNGARIAN GRAND ENTREPRENEURS IN THE SYSTEM OF NATIONAL COOPERATION: THE CHANCES OF CIVIL/BOURGEOIS DEVELOPMENT AFTER 2010 (AN EXTENSION OF THE RESEARCH)
}

\author{
MIHÁLY LAKI
}

\begin{abstract}
A non-conventional change of government occurred in Hungary in 2010. The winner of the election, party-alliance FIDESZ-KDNP, which controlled more than two-thirds of the seats in the Hungarian Parliament, transformed the Hungarian constitutional system radically and with unprecedented rapidity. The so-called invisible constitution of 1989 was replaced by a new Basic Law. The new holders of power changed the structure and management of state administration. There were also fundamental shifts in the system of public education and in the financing of the health care system. We witnessed the introduction of new and until-now never-applied approaches and tools for regulating the economy and the taxation system. Moreover, the new government introduced systemic changes in terms of how the poor and the unemployed were supported and modified the legal and financial status of local governments. Since 2010, the share of the state sector has increased in the Hungarian economy. How did the grand entrepreneurs behave, and what strategies did they use in this radically modified socio-economic environment?
\end{abstract}

KEYWORDS: entrepreneurs, market transformation, performance, failure

1 Laki, Mihály, HAS doctor, scientific adviser at the HAS Institute of Economics. E-mail: laki. mihaly@krtk.mta.hu 


\section{RESEARCH HISTORY}

Our team ${ }^{2}$ started a piece of quantitative research on the creation and development of the new capitalist strata in post-socialist Hungary nearly twenty years ago. There were two stages. In the first round (1999-2001), the main sources of information were forty-eight in-depth interviews which were amended and controlled through the content analysis of documents and newspapers. Our interview partners were owner-managers of fast-growing or efficiently consolidated large and medium-sized companies and businesses. Mainly because of their outstanding performance, these owner-managers were influential in the Hungarian economy at the end of the first decade of the postsocialist transition.

In this research project (and especially in the instructions for interviews) we focused on the micro- and macro-economic factors which would have been the main preconditions for successful post-socialist entrepreneurship. We carefully analyzed decisive events and turning points in family- or life histories which related to this process. Based on the interviews, we tried to understand the features which mobilized and speeded up the development of this phenomenon. Furthermore, we revealed diverse types of life stories and of aspirations (social roles), and specifically different structures of accumulated knowledge and skills as well. These results allowed us to evaluate the development of this emerging social group and place it in the context of the revival and rebuilding of the social functions of the Hungarian grand bourgeoisie. ${ }^{3}$

We started a follow-up piece of research about ten years after, in $2008 .{ }^{4}$ The core of our research plan was the idea to conduct a second round of in-depth interviews with our former partners. Accordingly, we undertook thirty-five follow-up interviews in 2009-2011. There were thirty-three cases in which we were able to meet our former interview partners again. In the other two cases, when our interlocutor had died in the meantime, we consulted with the owner-managers of the (descendant) company. We tried to reconstruct the stories of those who refused to contact us or had passed away. In these cases we used internet and media sources and communicated with successors.

2 Members included Julia Szalai, Ágnes Vajda and Mihály Laki. To our great sorrow, Agnes died in 1998. Following her desire, we continued with the research.

3 The main results of the research have been summarized in: Mihály Laki - Júlia Szalai (2006)

4 The research plan was completed in 2008, field work started in 2009, and the final version of the research report was published in 2012. Our research was supported by the Hungarian Scientific Research Fund (Tíz évvel később: magyar nagyvállalkozások az Európai Unióban OTKA 77918). 
The majority of our old-new interview partners were over forty years old during the first years of the post-socialist transition, so on good grounds we assumed that some of them would have already retired, or begun the complicated process of withdrawing from work in the period of our follow-up research. Furthermore, we expected that the methods and opportunities for company establishment would have significantly changed after the end of the last wave of privatization in Hungary (1997-1998). These two developments indicated the need for the involvement of a comparison group of younger Hungarian entrepreneurs into our research. Based on our earlier-used interview plan (including its thematic blocks), interviews were undertaken with thirty-one younger entrepreneurs (owner-managers of large or medium-size companies) in 2009-2012. Their common feature was that their businesses had started only since 2000 (thus we called them the 'younger' sample).

\section{UNEXPECTED DEVELOPMENTS AND THEIR UPSHOT}

Who lost a significant share of economic power and social influence?

In the last pages of our first book, we stepped away - perhaps unwisely from our position as descriptive researchers, and evaluated and calculated the hopefully positive impacts of this group of entrepreneurs on Hungarian society, saying that "The strategy of adaptation has again been successful, as the earlier statistical data indicate, and domestic grand business has been able to maintain its share and its position. In the light of such renewed success, EU accession seems to promise easier conditions and moving forward, rather than collapsing. Obviously, it is a new phase with new challenges for adaptation, but after all, this is the very area in which Hungarian grand entrepreneurs have for decades performed outstandingly well" (Laki-Szalai 2004 p. 228).

Unfortunately, our forecast, which was made in the first years of the twentyfirst century, needed significant modification. The evolution in the social position of the new strata of great entrepreneurs was not permanent (as we had claimed) but only provisional. We demonstrated in a second book (Laki-Szalai, 2015) that a significant component of this social group (the 'old' ones) - members of which had started businesses mostly during the first years of the post-socialist transition - had lost their influence and economic power by the end of the first decade of the twenty-first century. 
Table 1. Performance measured by company development (1990-1999)

\begin{tabular}{ccccc}
\hline \multirow{2}{*}{$\begin{array}{c}\text { Size of company at } \\
\text { start-up }\end{array}$} & \multicolumn{2}{c}{ Size of the company in the time of the interview } & \multirow{2}{*}{ Total } \\
\cline { 2 - 5 } & Small & Medium-size & Large & \\
\hline Small & - & 15 & 11 & 26 \\
Medium-size & - & 7 & 6 & 13 \\
Large & - & - & 7 & 7 \\
Uncertain & - & - & 2 & 2 \\
\hline Total & - & 22 & 26 & 48
\end{tabular}

The 'old ones' 1 had accumulated managerial experience and business connections at big state-owned companies and cooperatives, or in the illegal and legal private sector of the socialist system. Ten years after, we learned more about the drawbacks of this development, and recognized more precisely the negative returns of this hereditary endowment: i.e., the risk of the excessive accumulation of skills, knowledge and connections accumulated in the socialist era. We tried to understand that the failures were caused not only by the depreciation and obsolescence of this 'heritage'.

We identified specific 'traps', and typical cases of slow and inadequate adaptation. The sources of the fast growth of the first years of transition (the abundantly available stock of buildings and machines after privatization, the markets inherited or received from defunct state-owned companies, the consciously created familiar traits of the workplace) became barriers to further successful development. The old ones reluctantly fired their surplus (inefficient and incapable of learning) labor force, postponed technological modernization, and for them market change caused by saturation or by excess demand was mostly unusual. It is for these reasons that the performance of those members of the original sample weakened remarkably in the first decade of the new century. We were able to evaluate the performance of forty-three companies from the forty-eight in the years after 2000 based on our follow-up interviews, media news and information available on company home pages (Table 2).

Table 2 Performance measured by company development (2000-2008)

\begin{tabular}{ccccc}
\hline \multirow{2}{*}{$\begin{array}{c}\text { Size of company at } \\
\text { start-up }\end{array}$} & \multicolumn{3}{c}{ Size of company at time of interview } & \multirow{2}{*}{ Total } \\
\cline { 2 - 4 } & Small & Medium-size & Large & - \\
Small & - & - & - & 20 \\
Medium-size & 9 & 8 & 3 & 23 \\
Large & 6 & 2 & 15 & 2 \\
Uncertain & - & - & & 43
\end{tabular}


Interviews from the second round regularly contain reports about the disappointment of the older owner-managers. Not only did their stock of property diminish or disappear, but a significant number of them had withdrawn from public life and/or lost their previous social roles and functions since the time of first interview. The ambitions of these excellently performing, skilled owner-managers had in many cases changed over the last decade. Instead of trying to be symbols of excellence, they had sought to eliminate their image of disagreeableness, consciously mingled with the crowd, and stressed their conformity.

We emphasized in the second book the far-reaching impacts of this radical change of attitude that shows the apparent abdication of the promise and feasible-looking social role of this cohort, and of their plans to improve society.

We should add that we found that the new sample were already thinking on a smaller scale, and more about strengthening family frameworks. In this sense, in the circles of mid-size and larger entrepreneurs there are few representatives of the (big) bourgeois' attitude of wishing to have a say in the affairs of the country.

Our research highlighted multi-dimensional and deep differences between the old and new samples: it is as if these two groups do not belong to the same social strata. More precisely, as if they represented two clearly distinct status-groups. This shows how the norms and patterns represented by the old ones were not being followed by the others. The new ones are moving differently, in different spaces, and they have different aspirations and values. However, in order to exemplify the strata of big entrepreneurs, their common values, aspirations and behavioral patterns would have to be aligned with the attitudes of the (large) bourgeois' of wishing to have a say in the affairs of the country. The norms of the citoyen, who is ready to do something for the community, have somehow disappeared.

Not independent from this, displays of ideological attitudes have become more 'swampy'. Remarkably well-adapted to the changes in the ideological-political content of ordinary language (discourse), interviews with the old sample often contained indicative concepts, phrases, and figures of speech about so-called national discourse. We thus claim that ideological-political confessions have become externalized, and when necessary, easily commutable. However, dissemination of the norms of the strata of the former bourgeois would require robust and recognizable language. The delay in creating and refining such a language suggests a behavioral ethos which is based only the self-definition of the private person and a kind of responsibility based on the boundaries of the private personality.

We recognize the deepening controversy about 'relations with the rest of the world' as being among the limitations of the sample, applying to (big) bourgeois' 
attitudes as well. It is as if the middle-size and larger entrepreneurs we interviewed had adapted to the newest wave of xenophobia which overwhelmed Hungary in the last year of the republic in 1989 (Sik 2012). Europe at that time was not yet the desired point of reference, or the depository of ideas about freedom and welfare, but was becoming a source of unpleasant burdens. Our interview partners mentioned the over-bureaucratic nature of the Union, and its pointless but qualified rules. They complained about the unequal distribution of European benefits among member states. They cited as the cause of their personal failure multinational companies - representing 'foreigners'. Compared to such events, any counterbalancing advantages of the Union were minimized. Among these subordinated factors are the knowledge that can be obtained from these foreign owned-managed companies of production-culture, organization management, and labor policies at a company level.

Meanwhile, members of the old and the new sample rely on foreigners very often. We see that they enjoy the freedom of movement and travel - which involves opportunities for learning, recreation and cultural facilities. But we must also recognize that, along with the pragmatic mention of these advantages, comes a strong demand for national isolation. Freedom becomes a private good, but in terms of public interest, "abroad" is very often a source of disappointment and suggests barriers. This attitude renounces the former desire for the adoption of European standards and rejects the conception that Hungarians as European citizens could create a new identity. And through this capitulation, respondents recognize implicitly the provincial character of the country - and of the national community - preferring to respect the long-term peripheral status of Hungary. The promising process of the construction of the elite roles of the great entrepreneurs practically disappeared before the radical change of the political system in 2010 .

\section{AFTER THE FALL OF THE REPUBLIC OF 1989}

We did not consider that the republic of 1989 would fall in the previous two stages of our field work. Moreover, our interview partners (large entrepreneurs, owner-managers) had not incorporated the above-mentioned institutional and regulatory changes into their expectations in business plans.

We did not undertake field work after 2012. Based on internet, media sources and on personal communication, we used secondary information only at this stage. Collection of information was focused but not restricted to our previous interview partners, but we documented news reports and interviews with other owner-managers of companies with a Hungarian majority share. We preserved 
the anonymity of our previous interview partners, thus stories and examples were collected from outsiders.

\section{Shrinkage of output and exit from the market: earlier developments continue}

The withdrawal from the business sector of older (retirement-age) ownermanagers continued over the last 3-4 years. In some cases, companies were passed on to children, or to a selected successor, and owner-managers retired. These exits, company sales, or significant cases of shrinkage were driven by strong constraints, not by free and voluntary calculations, or by the desire to carefully maximize income, in most cases.

Some constraints, such as difficulties with sales and liquidity problems, are of market origin: the typical business failures of the old sample repeated themselves. A business plan which incorporated a miscalculation about growth in turnover caused the collapse of Ulpius Publishing House (F. Szabó 2015). A similar outcome occurred on the same market when another great entrepreneur/ owner-manager, Mr. Dezső Matyi, failed to accurately estimate the growth rate of the Hungarian book market, causing serious liquidity problems at Alexandra Publishing Company (F. Szabó 2014, 2014a, Hamvay 2012). Similar market failures occurred in other industries such as road building (Vitézy 2013).

\section{(Partly) new reasons for failures and retirements}

Another significant reason for these business failures and shrinkages was the direct influence of politicians, or the buying pressure of companies with close relationships to the governing political coalition. For example, Magyar Építő Zrt. (Hungarian Construction Ltd.) was bought by a businessman who belongs to the prime minister's circle of friends. "Mr. Tibor Tolnay, the previous owner of the company, did not tell us the price at which - according to him - he would be satisfied. At the same time, he made it clear that nothing would make him leave. He considered it most important that the 108 employees would have a safe working place under the management of the new owners" (Gépnarancs 2015). Another owner-manager in our sample inaugurated a collaborative project with a newly elected, FIDESZ-delegated mayor. However, a week later the local government terminated the deal and gave the business to someone else. Events and stories like these contributed to the change in the business climate. 
Mostly, it was the so-called Simicska-case that convinced entrepreneurial society that the redefined procurement policy of the FIDESZ-controlled Hungarian state would decisively influence the income and profit of numerous companies; moreover, in a lot of cases such decisions would practically define the future development of these companies and the success of their owners. The Közgép-conglomerate, a network of companies which are/were ownedmanaged by Mr. Lajos Simicska, a former close friend and dorm-mate of the prime minister, won numerous public orders for many years (Bednárik-Nyusztay 2015). The Hungarian business community watched with interest when, after the eruption of a serious personal-political conflict between Simicska and the prime minister, Közgép lost all procurement tenders that affected this companynetwork. This development influenced negatively the profitability and the market share of the Simicska-owned conglomerate. The peak of the new form of negative discrimination happened when this company group was excluded from the entire Hungarian procurement process for years because of so-called irregularities with an application which was submitted as part of a tender for the construction of a port at Gönyü (a small town on the bank of the Danube in West Hungary). Some of this company network's earlier contracts were also cancelled in the meantime. The 'Simicska Empire' was forced to make layoffs, and its financial position has weakened significantly since the Simicska-Orbán affair (Kapitány-Szabó-Varga 2015). At the same time, companies and companychains owned and managed by Lörinc Mészáros, a friend and village neighbor of Prime Minister Viktor Orbán, grew rapidly in terms of turnover and profit, elevating Mészáros (formerly a local village plumber and small businessman) onto the list of the 100 richest Hungarians in less than two years (Lencsés 2015). Companies belonging to the prime minister's son-in-law won a long list of local government tenders, in a majority of cases being the only applicants. Such stories about the punishment-and-reward activities of the state sent a message to the Hungarian business community that success on the procurement market was no longer connected to performance, but political contacts. More precisely: political dependency appears to be higher in Hungary than it was before 2010 .

On markets in which the share of the state procurement is traditionally marginal or collateral we may also recognize significant regulatory changes which have variously affected the performance of companies. We can mention here, among others, bank nationalizations and the introduction of industryspecific taxes in some key sectors of the Hungarian economy. The re-regulation of the tobacco retail trade provoked the biggest reaction from the public and market players in the last few years. The re-regulation of this market involved not only the nationalization of the tobacco retail trade, but the imposition of mandatory concession contracts for new market entrants (Laki 2015). 
The tobacco retail trade story is not an exception. The government has radically modified regulations which have affected the listing and power ranking of market players on the textbook market (Átlátszó 2013). Similar interventions have taken place in the markets for company liquidator agencies, video games, and the market for the construction design of state projects. Partial-temporary restructuring of the pharmacy market was also on the agenda (Laki 2015).

Circulating news about the further restructuring of markets strengthened pessimistic expectations and increased the uncertainty of the Hungarian business community. For example, news about the reorganization of the alcohol (wine, beer, and spirits) trade along the lines of the tobacco market regulation was in the air (Index 2013a). The prime minister has also confirmed that the series of nationalizations and market restructurings are far from over: "As for the prime minister, there will be heavier matters in the future. They will provoke similar debates, because - as the prime minister said - 'we have managed such steps of reorganizing the market in this cycle, and will in the future as well. If we are convinced that we can give a chance to small and medium-sized companies, then, if necessary, we will intervene, and reorganize things - within the law, and respecting the European rules about competition, of course"' (Index 2013b).

\section{Experiments with adaptation}

The so-called national oligarchs - those who are supported by the FIDESZ government - grab at the above-mentioned opportunities and take advantage of the selectively supported expansion of the market, which seems to be one of the specific features of the 'System of National Cooperation' (Nemzeti Oligarchák Újgazdasági Mechanizmus 2014). But what kind of strategies were used or tested by members of our sample? How did the old and the new sample adapt to these new conditions?

Besides the previously documented (sometimes unusual) market exits and shrinkages, a few respondents from these two groups have carefully adapted to the new political conditions. The simplest case was when one of the new respondents successfully invited the prime minister as a guest of honor to a factory inauguration ceremony.

The behavior of those entrepreneurs who have transferred the center of gravity of their businesses to other countries in the last two years may be more important in terms of impact (only a few similar instances of this took place in the past). In other words, it is not only labor, but capital which has 'emigrated' from Hungary too. For example, one of the members of our sample joined an 
international product consortium. Some sentences from the great entrepreneur György Gyattyán - who did not belong to either sample - clearly illustrate the reason for and approaches to relocating businesses and businesspeople nowadays: "My businesses are working through the internet. My company's income is not derived from Hungary. I live abroad. I do not attend private receptions here. I have no insider connections. I am not familiar in some circles, so to say. Unfortunately, I missed the chance to build connections and a name for myself. This should have started five years ago" (Várkonyi 2014).

One emblematic figure from the 'old' days, Sándor Demján (who was not a member of our sample either), who plays a significant public role in contemporary Hungary, underwent a similar journey. Because of liquidity problems, subcontractors prosecuted one of his companies (Fekete 2015). Demján "sold a significant part of the mortgage-portfolio of his successful company Trigránit. The buyer was the American company TPG which is practically unknown in Hungary, although it is considered among the gigantic investment companies" (Népszabadság 2015b). This step made Demján's investment policy even more obvious: "in the last years the Trigránit-group typically increased their share of property abroad because the business climate of Hungary did not favor such investments" (Vitézy 2015 p. 54).

\section{CAREFUL COMMENTS ABOUT THE FURTHER OPPORTUNITIES OF OUR INTERVIEW PARTNERS}

The future of the institutional and market structure which has been shaped by the new power holders since 2010 is uncertain. In other words, we cannot currently describe it as a self-sustaining system which is able to self-correct. But we may offer the following weak but plausible argument: the above-collected and presented anecdotes about the events and stories of the last 2-3 years rather suggest that the regulative activities and economic policy of the new regime, and the responses of business people to these developments, are more favorable to the spread of a mentality (and relationships) of dependency, rather than to the strengthening of free and independent citizenship.

Unfortunately, there are no reasons for modifying the following sentences contained in the book we published in 2013: "The promising start to the elite roles of the great entrepreneurs has nowadays dissipated. It seems to us that their disappearance is more or less irreversible. But a pragmatic social-political reform program cannot be achieved without strengthening value-creating elites. Therefore, the often-mentioned hopeless situation of the country is becoming permanent. It is not the task of this study to consider the alternatives. But we may 
state, perhaps, that we cannot imagine how the marginalization of the country in the European space may be halted and a path of modernization developed without the emergence of a strata of mid-level and larger entrepreneurs which relies on its own strength. Which trustfully and, in perspective, feels that it has found its place again, and has enough spirit and energy to create a role for itself as the driving force of our country" (Laki-Szalai 2015 p. 208-209).

\section{REFERENCES}

Átlátszó (2013), http://atlatszo.hu/2013/07/30/leszerepelt-esztergomifideszesekre-biztak-a-tankonyvpiac-allamositasat/, January 30, 2016.

Bednárik, Imre - Nyusztay, Máté (2015), "A nagy Simicska ciklus Egy cégbirodalom története", Népszabadság, Hétvége, February 14, pp 22-23.

Fekete, Gy. Attila (2015), "Nyomoznak az Arcadom ellen. Kifizetetlen számláik miatt alvállalkozók fordultak a hatósághoz", Népszabadság, March 23-24, p. 13.

F. Szabó, Emese (2014), "Matyi Dezső tovább küzd. A könyvkereskedő cégei késnek a mérlegek, benyújtásával, ellenük végrehajtások indulnak", Népszabadság, June 27, p. 10.

F. Szabó, Emese (2014a), "Milliárdok forognak kockán. Matyi Dezső több év haladékot kért a kiadók felé fennálló tartozásai törlesztésére”, Népszabadság, August 21 p. 5.

F. Szabó, Emese (2015), "Indul az Ulpius felszámolása, Bár eredménytelen volt a csődegyezségi tárgyalás, továbbra is kiadó megmentése a felek célja", Népszabadság, September 19, p. 7.

Gépnarancs (2015), http://gépnarancs.hu/2015/02felcsuti-fenyben-ragyog-amagyar-epito, 2016 January 30

Hamvay, Péter (2014), "Belefulladt a szemétbe. Az Ulpius ház végromlása", Magyar Narancs March 2, pp. 32-33.

Hamvay, Péter (2014a), "Fizet, nem fizet, fizet, nem fizet? Mikor jön egyenesbe az Alexandra?", Magyar Narancs, July 3, pp. 11-13.

Index, (2013a) (http://index.hu/gazdasag/2013/05/30/jonnek_a_nemzeti_ italboltok/, 2016. January 30.

Index,(2013b)http://index.hu/belfold/2013/05/30/orban_lesznek_meg_ piacokat_atszervezo_lepeseink/, 2016. January30.

Kapitány Szabó, Attila - Varga, G. Gábor (2015), "Haláltusa a Közgépnél. Háromszázötven dolgozóját bocsátja el Simicska Lajos cége", Népszabadság, October 14. p. 2. 
Laki, Mihály (2015), "Restructuring and re-regulation of the Hungarian tobacco market" Corvinus Journal of Sociology and Social Policy", Vol. 6 No 2. pp 39-73.

Laki, Mihály (2017), “Két történet: a gyógyszertárak piaca 2010 után", Külgazdaság Vol. LXI. Nr. 11-12. pp. 80-104.

Laki, Mihály - Szalai, Júlia (2004), Vállalkozók vagy polgárok? Budapest. Osiris Kiadó

Laki, Mihály - Szalai, Júlia (2006), "The Puzzle of success Hungarian entrepreneurs at the turn of Millennium", Europe-Asia Studies Vol. 58. No. 3. pp. 317-347.

Laki, Mihály - Szalai, Júlia (2015), Ten years after: Hungarian Grand Entrepreneurs in the European Union, Budapest, Published by the Institute of Economics, Hungarian Academy of Sciences.

Lencsés, Károly (2014), "Nem érti miért érdekes. Mészáros Lőric: Négy év alatt százszorosára nött a polgármester jövedelme.” Népszabadság, June 20, p 4.

Nemzeti Oligarchák Újgazdasági Mechanizmus (2014), HVG Fókuszban, March 15. pp 6-10.

Népszabadság (2015): “Osztalékeső hullott Simicskára. Tavalyi nyeresége után 38 milliárd forintot fizetett ki a cégcsoport”, Népszabadság, June 6. p. 6.

Népszabadság (2015a), “Demján kiszáll a Trigránitból”, August 11. p. 7.

Sík, Endre (2012), "Nem mérlegelünk - nem kellenek az idegenek”, Budapest, TÁRKI

Vitézy, F. Ibolya (2013), “Csőd után. Vegyépszer - adósság - rendezés”, Heti Világgazdaság, August 10, pp. 56-57

Vitézy F. Ibolya (2015), “Aranybányából aranybányába Demján Sándor újabb nagy üzlete", Heti Világgazdaság, August 22. pp. 53-54

Várkonyi, Iván (2013), "Izgalmas bulvárhír vagyok. A televízió képernyőjére álmodja az internetes közvetítést a milliárdos”, Népszabadság, October 14. p. 11. 